\title{
Sensory and chemical evaluation of tea brews prepared with the assistance of ultrasound
}

\author{
Radosław Kowalski ${ }^{*}$ (D) Jakub Wyrostek ${ }^{1}$ Klaudia Kałwa ${ }^{1}$ Grażyna Kowalska $^{2}$ (D) \\ Urszula Pankiewicz ${ }^{1}$ (D) Monika Sujka ${ }^{1}$ (D) Marzena Włodarczyk-Stasiak ${ }^{1}$ (D) Artur Mazurek ${ }^{1}$
}

\footnotetext{
${ }^{1}$ Department of Analysis and Evaluation of Food Quality, University of Life Sciences in Lublin, 8 Skromna Street, 20-704 Lublin, Poland. E-mail: radoslaw.kowalski@up.lublin.pl. "Corresponding author.

${ }^{2}$ Department of Tourism and Recreation, University of Life Sciences in Lublin, Lublin, Poland.
}

ABSTRACT: The aim of the study was to evaluate sensory and phytochemical (polyphenols, flavonoids and caffeine) estimation of black and green tea brews obtained in an alternative way through brewing with the assistance of ultrasound. Brews produced with the application of sonication for 2 minutes and 1 minute were the most preferred by the sensory evaluation team. Evaluation of the brews in terms of component descriptors, i.e. fragrance, flavour and colour, was varied and depended on the kinds of tea and on the applied experimental factors. It was demonstrated that ultrasound have a significant effect on the extraction of active substances, i.e. polyphenols, flavonoids and caffeine, from black and green tea. The application of sonication caused a significant increase in the concentration of flavonoids (by ca. 29\% and 73\%), polyphenols (by ca. $34 \%$ and $41 \%$ ) and caffeine (by ca. $51 \%$ and $60 \%$ ) in the tea brews.

Key words: tea brews, sonication, sensory, phytochemical analysis.

Avaliação sensorial e química de infusões de chás preparados com o emprego do ultrassom

RESUMO: O objetivo do estudo foi verificar a atividade sensorial e fitoquímica (polifenóis, flavonóides e cafeina) de infusões de chá preto e verde empregando o ultrassom. As infusões produzidas com a aplicação de sonicação por 2 e 1 minutos foram as mais preferidas pela equipe de avaliação sensorial. A avaliação das infusões em termos de descritores de componentes, isto é, fragrância, sabor e cor, foi variada e dependeu dos tipos de chás e dos fatores experimentais aplicados. Foi demonstrado que o ultrassom tem um efeito significativo na extração de substâncias ativas, ou seja, polifenóis, flavonóides e cafeína, do chá preto e verde. A aplicação de sonicação causou um aumento significativo na concentração de flavonóides (em cerca de 29\% e 73\%), polifenóis (em cerca de 34\% e 41\%) e cafeína (em cerca de $51 \%$ e $60 \%$ ) das infusões de chá.

Palavras-chave: infusões de chá, sonicação, sensorial, análise fitoquímica.

\section{INTRODUCTION}

During the past 20 years tea has been the object of numerous studies, focusing mainly on its health-promoting properties. Tea is one of the most popular drinks in the world. Tea is drunk by about $75 \%$ of consumers more than once a day (KRAUJALYTE et al., 2016). Tea is a rich source of bioactive components affecting the quality of the obtained brews (SOMESWARARAO \& SRIVASTAV, 2012). In terms of chemical properties, tea contains alkaloids (caffeine, theobromine, theophylline), flavonoids (polyphenolic compounds, catechins, tannins), minerals and compounds occurring in leaves of other plants, such as saccharides, proteins, lipids or chlorophyll (WEISBURGER, 1997). Apart from the above components, teas contain also organic acids (citric acid, oxalic acid, malic acid, succinic acid, pyruvic acid, fumaric acid), which causes a notable improvement of the nutritional and dietary values of tea (GASIŃSKA \& GAJEWSKA, 2007). Brews of black and green tea are a rich source of phenolic compounds which cause a reduction of the risk of contracting numerous chronic diseases. Regular drinking of tea reduces the risk of neoplastic diseases and diseases of the cardiovascular system, slows down the process of ageing, reduces hypertension and the level of cholesterol, and has antibacterial and antivirus effects. Numerous studies confirmed the beneficial effect of polyphenols contained in tea brews in the protection of the cardiovascular system, prevention of cancer, neurodegenerative diseases or diabetes (HIGDON \& FREI, 2003; ZHU et al., 2016). As consumers, we are interested in obtaining from the raw material a brew that will be characterized by a high content of biologically active substances, 
without forgetting about components that have an effect on the sensory evaluation of the ready brew. Hence, the importance of all research resulted in the selection of the optimum technique of tea brewing, e.g. with the assistance of ultrasound.

Application of ultrasound in numerous areas of life and in many technological processes has become the object of study by scientists and process engineers. The application of ultrasound comprises their use in test and measurement apparatus, as well as in food production - for improvement of the processes of blending, extraction, crystallization, decrease of viscosity, sterilization, filtration and drying (MASON, 1999). Application of the ultrasound-augmented variant of extraction provides many possibilities in the food as well as the pharmaceutical industries. An over $30 \%$ increase of efficiency of herbal extracts from marigold, mint, hop and dill was noted in a study by VINATOUR (2001). Whereas, increased efficiency in the case of extraction of polyphenols, caffeine and amino acids in green tea brews was observed also by XIA et al. (2006).

In recent years one can observe increasing consumer awareness with regard to food products. More often consumers pay attention to the chemical composition of food products, and especially to their content of health-promoting components not importing their sensory quality. For this reason in the evaluation of the quality of food products, apart from the analysis of their chemical composition, also the sensory evaluation is performed that allows the attractiveness of the products in terms of consumer preferences. Results of sensory evaluation are affected by chemical components of food products that determine the perception of such traits as e.g. fragrance, flavour and colour (CARBONELLBARRACHINA, 2007). Therefore, in the experiment presented herein, an alternative method of preparation of green and black tea involving the use of sonication was applied, and sensory evaluation of the obtained tea brews was performed. In addition, an estimation was made of the content of active substances, i.e. polyphenols, flavonoids and caffeine, in traditional brews and in those obtained with the modified method with the assistance of ultrasound.

\section{MATERIALS AND METHODS}

The experimental material consisted of the following tea brands available on the consumer market - loose green tea (Herbapol-Lublin S.A., Poland) and loose black tea "Golden Assam" (Girnar Exports, India) purchased at a supermarket in Lublin in the year of 2014 - four batches of each commercial brand. Individual batches of tea were combined, mixed and ground to the same fraction.

Tea brews were prepared in conformance with the POLISH STANDARD PN-ISO 3103 (1996) "Tea - Preparation of liquor for use in sensory tests". A portion of $2 \mathrm{~g}$ of tea leaves was weighed in a beaker, and then poured over with $100 \mathrm{~mL}$ of freshly boiled deionised water and left to brew under cover for 6 minutes (control). After that, leaves were separated from the brew which was to be used for analyses.

Portions of $2.00 \mathrm{~g}$ of leaves of the analysed teas were weighed in laboratory beakers and poured over with $100 \mathrm{~mL}$ of freshly boiled deionised water and covered with wristwatch glass; next the samples were subjected to sonication in ultrasonic bath (Sonic-6, Polsonic, Poland) with ultrasound power, $240 \mathrm{~W}$; frequency, $40 \mathrm{kHz}$ for periods of $0.5,1,2,3,4$ and $6 \mathrm{~min}$, temp. $95^{\circ} \mathrm{C}$ (capacity of an ultrasonic bath - 5.7 L, amount of water in an ultrasound bath - 4.5 $\mathrm{L}$, position in an ultrasonic bath - immersion to the infusion level, single beakers were placed in the bath in a central position). After the preset times of brewing the plant residue was separated from the ready brew which was then used for the analyses. Table 1 presents

Table 1 - Compilation of analysed samples of tea brews.

\begin{tabular}{lccc}
\hline Sample code black tea & Sample code green tea & Brewing time (min) & The use of sonication \\
\hline B_N & G_N & 6.0 & - \\
B_U0.5 & G_U0.5 & 0.5 & + \\
B_U1.0 & G_U1.0 & 1.0 & + \\
B_U2.0 & G_U2.0 & 2.0 & + \\
B_U4.0 & G_U4.0 & 4.0 & + \\
B_U6.0 & G_U6.0 & 6.0 & + \\
\hline
\end{tabular}

Ciência Rural, v.49, n.11, 2019. 
a compilation of the analysed samples of tea brews which were given suitable identification codes.

Sensory analysis of the brews was conducted with regard to general preferences (indication by the assessor of a single sample of brew preferred in terms of sensory traits), with the use of a hedonic scale, determining the degree to which a given sample is "desirable" or "undesirable" to the consumer. A 5 point scale was used: like very much $(+2 \mathrm{pts})$, like $(+1 \mathrm{pt})$, neither like nor dislike (0 pts), dislike $(-1 \mathrm{pt})$, dislike very much $(-2 \mathrm{pts})$ (BARYŁKO-PIKIELNA \& MATUSZEWSKA, 2014; SZCZESNA et al., 2005). In addition, sensory evaluation in terms of fragrance, flavour and colour was conducted with the use of the ranking test in which every sample was given a suitable rank, from the least intensive fragrance/flavour/colour (rank 1) to the most intensive fragrance/flavour/colour (rank 7) (BARYŁKO-PIKIELNA \& MATUSZEWSKA, 2014). Results obtained for a particular trait were summed up and expressed in a percentage scale, where the highest rating of a given trait corresponded to $100 \%$. Sensory evaluation of the analysed tea brews was performed by a 13-person group of consumers with verified high sensory sensitivity.

Determination of flavonoid content (flavonoles converted for quercetin) in the tested brews was performed by means of spectrophotometry $(\lambda=425 \mathrm{~nm})$ according to a modified Polish Pharmacopoeia VI (2002) procedure by formation of a complex with aluminium chloride after acidic hydrolysis of extracts. Determinations of phenolic compounds (with conversion for gallic acid) in the tested brews were made by spectrophotometric means $(\lambda=765 \mathrm{~nm})$ according to a modified SINGELTON \& ROSSI (1965) method. Determination of caffeine concentration in the tested brews was performed by means of spectrophotometry $(\lambda=273 \mathrm{~nm})$ according to international standard method by YAO et al., (1993), and YAO et al. (2006).

Data were analyzed by analysis of variance (Duncan's test) at 5\% significance level using the SAS statistical system (SAS Version 9.1, SAS Inst., Cary, N.C., U.S.A.).

\section{RESULTS AND DISCUSSION}

Sensory evaluation of the tea brews to determined how significant is the effect of green and black tea brewing method on the sensory traits of the brews (Table 2). With regard to the preference ranks, the evaluating team decidedly indicated black and green tea brews prepared with the assistance of ultrasound -9 and 6 persons, respectively, which chose brews obtained with 2 minute sonication, and 3 persons each selected the brew obtained with 1 minute sonication. In the hedonic analysis (similarly to the analysis of preferences) the highest scores were awarded to brews of green and black tea prepared with the assistance of ultrasound for 1 and 2 minutes (G_U2.0, G_U1.0, B_U2.0, B_U1.0), and the lowest scores were those given to the black tea brew prepared with the use of sonication for 4 minutes, B_U4.0, and the green tea brew prepared with the classic method (control), G_N (Figure 1). Brews of green and black tea obtained with the assistance of ultrasound for $1 \mathrm{~min}$ and $2 \mathrm{~min}$ received higher scores from the assessors compared to brews prepared with the classic method.

In the case of the evaluated black tea brews, longer time of brewing with the assistance of ultrasound caused the obtainment of higher ranked colour of the brew (Figure 2). For example, with regard to the colour the black tea brew obtained

Table 2 - Results of sensory assessment of tea brews using the preference method.

\begin{tabular}{lccc}
\hline Sample code & The number of answers & Sample code & The number of answers \\
\hline G_N & 1 & B_N & 1 \\
G_U0.5 & 0 & B_U0.5 & 2 \\
G_U1.0 & 3 & B_U1.0 & 3 \\
G_U2.0 & 9 & B_U2.0 & 6 \\
G_U4.0 & 0 & B_U4.0 & 0 \\
G_U6.0 & 0 & B_U6.0 & 1 \\
\hline
\end{tabular}

*designations as in Table 1. 


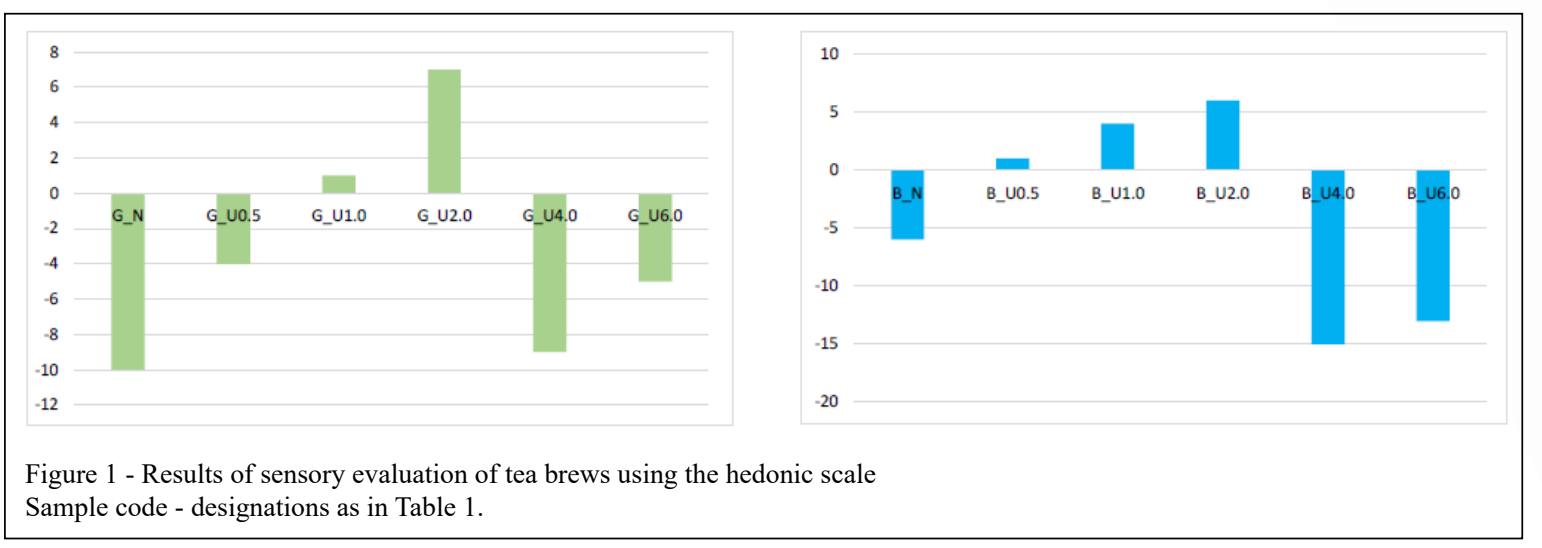

during the 0.5 minute process of brewing with sonication received a rank equivalent to $37 \%$, while the brew prepared during 1 minute with sonication received a score of $58 \%, 2 \min -59 \%, 4 \min 63 \%, 6$ $\min -57 \%$. The highest ranked with regard to flavour was the black tea brew prepared during 6 minutes with sonication $-73 \%$, while the control sample without ultrasonic augmentation $-60 \%$. Black tea brews obtained with the assistance of ultrasound for times from 0.5 to 4 minutes were characterized by the following ranks: B U0.5-46\%, B U1.0-43\%, B_U2.0-60\%, B_U $4.0-69 \%$. Whereas, with regard to fragrance the highest ranked were black tea brews obtained with the classic method, B_N - 66\%, and with sonication for 4 minutes, B_U4.0 - 73\%.

In the case of the colour of green tea brews, the colour of brew obtained with the classic method was characterized by the highest score - $76 \%$, while brews obtained with sonication for $0.5,1,2$ and 4 minutes received similar scores - $51 \%$, and the brew obtained with the assistance of ultrasound during 6 minutes - $69 \%$. The highest score for flavour was that awarded to green tea brew prepared during 1 minute with sonication $-66 \%$, while that for the control sample without sonication was $54 \%$. Green tea brews obtained with the method with sonication during $0.5,2,4$ and 6 minutes were characterized by the following scores in flavour evaluation: G_U0.5 $56 \%$, G_U2.0-47\%, G_U $4.0-44 \%$, G_U6.0 $-56 \%$. With regard to the parameter of fragrance, the highest ranked were the tea brews obtained with the method with the assistance of ultrasound for 6 and 2 minutes, respectively, G_U6.0 - 65\% and G_U2.0 - 60\%, while the rank awarded to green tea brew prepared with the classic method, G $\mathrm{N}-52 \%$.

Table 3 presents the concentration of flavonoids, polyphenols and caffeine in the analyzed tea brews, while the graph in figure 3 illustrates changes in the concentration of the analyzed substances, expressed in percentage values in relation to the same concentrations in the control tea brews prepared in the traditional manner during 6 minutes. The analyses showed that the content of flavonoids (as converted to quercetin) in the tea brews was dependent on the kind of tea, brewing time, and on the applied sonication. Control brew of black tea (brewed in the traditional way) had flavonoid content of 1.55 $\mathrm{mg} / 100 \mathrm{~mL}$. A similar concentration of flavonoids was noted in the sample subjected to sonication for 2 minutes (B_U2.0). The highest concentration of flavonoids was characteristic of the brew obtained with 6 minutes of sonication (B U6.0), at the level of $2.00 \mathrm{mg} / 100 \mathrm{~mL}$, while the lowest flavonoid content was noted in brew B_U0.5 - $1.09 \mathrm{mg} / 100$ $\mathrm{mL}$. In the case of green tea the control brew ( $\left.\mathrm{G} \_\mathrm{N}\right)$ had flavonoid content of $6.64 \mathrm{mg} / 100 \mathrm{~mL}$, while that of the brew obtained with the use of sonication lasting for $0.5 \mathrm{~min}$ (G U0.5) was at a similar level - $6.18 \mathrm{mg} / 100 \mathrm{~mL}$. The maximum concentration of flavonoids in brews of green tea was noted in the case of sonication applied in the variant G_U6.0 - 11.49 $\mathrm{mg} / 100 \mathrm{~mL}$, which increased by ca. $7 \overline{3} \%$ compared to the concentration in the traditionally brewed green tea and ca. 7.41-fold higher compared to traditionally brewed black tea.

Figure 3 presents the percentage differences in the concentrations of the particular active substances in the analyzed variants of tea brews in relation of the control brew obtained as a result of 6-minute traditional maceration. There is a distinct tendency of increase of flavonoid concentration in the analyzed tea brews with extension of the time of brewing with sonication.

Results obtained in the study presented here indicate that green tea brews have a significantly 


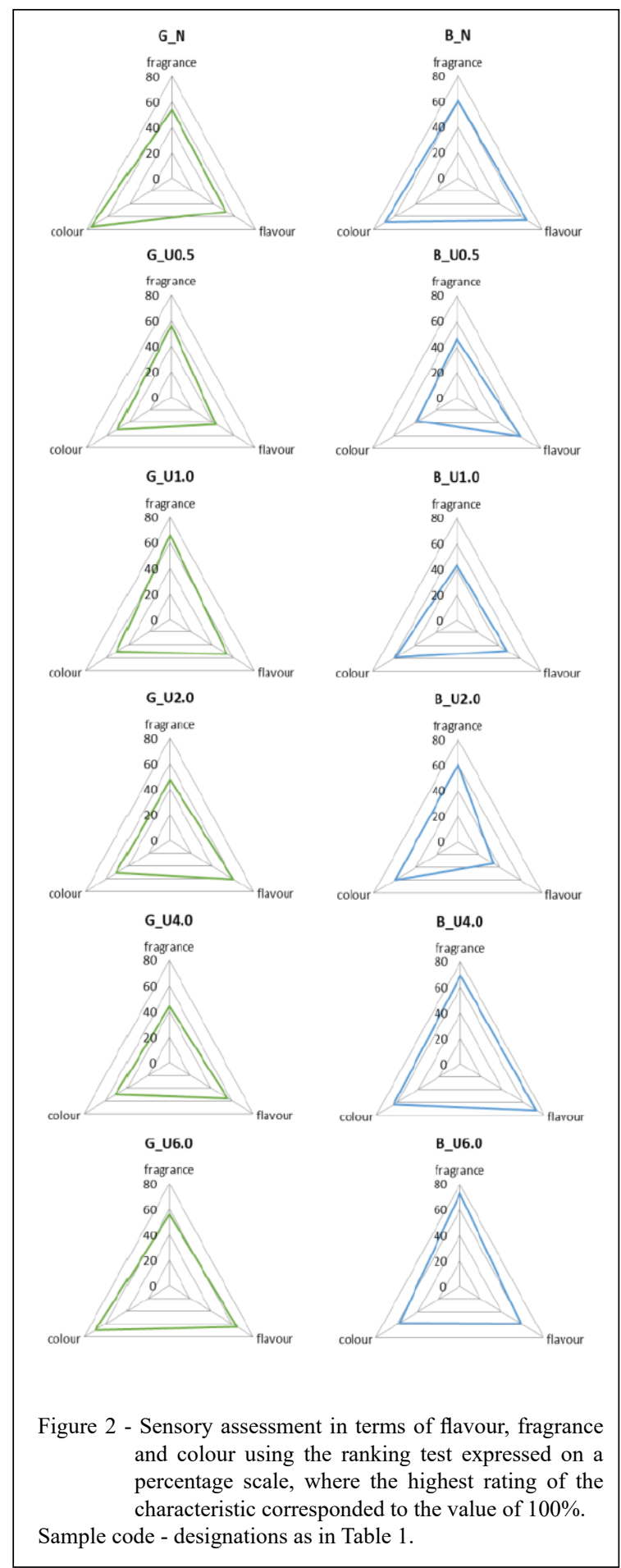

higher concentrations of flavonoids compared to black tea brews. A similar relation was reported by PERUCKA (2001) in her study. In addition, in this study it was observed that an extension of the time of tea browing augmented with sonication caused a significant increase in the concentration of flavonoids, which is also supported in other research reports. Increased levels of polyphenolic compounds in tea brews lead to an increase of antioxidant activity of the brew (LIEBERT et al., 1999). WANG et al., 
Table 3 - Concentration of flavonoids, polyphenols and caffeine in the analyzed tea brews obtained in the traditional manner and with sonication.

\begin{tabular}{|c|c|c|c|}
\hline \multirow[t]{2}{*}{ Sample code ${ }^{*}$} & \multicolumn{3}{|c|}{ - } \\
\hline & flavonoids & polyphenols & caffeine \\
\hline \multicolumn{4}{|c|}{ 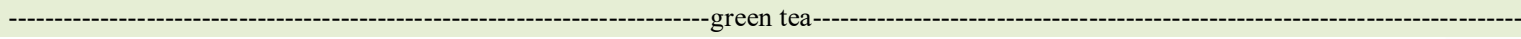 } \\
\hline G_N & $6.64 \pm 0.27$ ef & $54.79 \pm 2.16 f$ & $20.37 \pm 0.85 \mathrm{f}$ \\
\hline G_U0.5 & $6.18 \pm 0.26 \mathrm{f}$ & $36.10 \pm 1.20 \mathrm{i}$ & $19.96 \pm 0.77 \mathrm{f}$ \\
\hline G_U1.0 & $9.41 \pm 0.38 \mathrm{~d}$ & $38.03 \pm 1.11 \mathrm{hi}$ & $20.58 \pm 0.80 \mathrm{f}$ \\
\hline G_U2.0 & $10.11 \pm 0.42 \mathrm{~cd}$ & $56.16 \pm 2.14 \mathrm{ef}$ & $27.52 \pm 1.17 \mathrm{e}$ \\
\hline G_U4.0 & $11.03 \pm 0.47 \mathrm{bc}$ & $62.84 \pm 3.16 \mathrm{~d}$ & $31.91 \pm 1.12 \mathrm{~d}$ \\
\hline G_U6.0 & $11.49 \pm 0.56 \mathrm{ab}$ & $77.51 \pm 3.15 \mathrm{ab}$ & $32.50 \pm 1.10 \mathrm{~d}$ \\
\hline \multicolumn{4}{|c|}{ 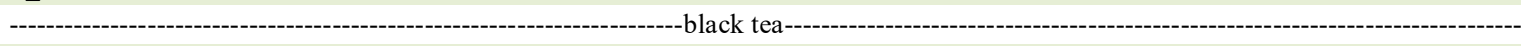 } \\
\hline B_N & $1.55 \pm 0.10 \mathrm{i}$ & $54.38 \pm 2.30 \mathrm{f}$ & $33.58 \pm 1.12 \mathrm{~d}$ \\
\hline B_U0.5 & $1.09 \pm 0.09 \mathrm{k}$ & $29.64 \pm 1.34 \mathrm{j}$ & $33.43 \pm 1.11 \mathrm{~d}$ \\
\hline B_U1.0 & $1.32 \pm 0.07 \mathrm{j}$ & $40.61 \pm 2.21 \mathrm{gh}$ & $38.26 \pm 1.12 \mathrm{c}$ \\
\hline B_U2.0 & $1.55 \pm 0.09 \mathrm{i}$ & $41.90 \pm 2.14 \mathrm{~g}$ & $45.82 \pm 2.15 b$ \\
\hline B_U4.0 & $1.78 \pm 0.09 \mathrm{hi}$ & $67.36 \pm 3.10 \mathrm{~cd}$ & $49.93 \pm 2.19 \mathrm{ab}$ \\
\hline B_U6.0 & $2.00 \pm 0.13 \mathrm{gh}$ & $73.07 \pm 3.16 b c$ & $50.55 \pm 2.14 \mathrm{a}$ \\
\hline
\end{tabular}

*designations as in Table 1.

Values designated with the same letters ( $a, b, c . .$.$) within column do not significantly differ at 5\% error (Duncan's test).$

(2000) demonstrated that with extension of brewing time the content of catechins and flavonols decreases, which is contrary to other reports.

The control sample of black tea (B_N) was characterised by polyphenols content, converted to gallic acid, at the level of $54.38 \mathrm{mg} / 100 \mathrm{~mL}$. The highest content of polyphenols in black tea brews was characteristic of the sample obtained with sonication applied for $6 \mathrm{~min}$ (B U6.0), the concentration of that group of substances being at the level of $73.07 \mathrm{mg} / 100$ $\mathrm{mL}$, which means that the content of polyphenols in that sample increased by ca. $34 \%$ compared to the

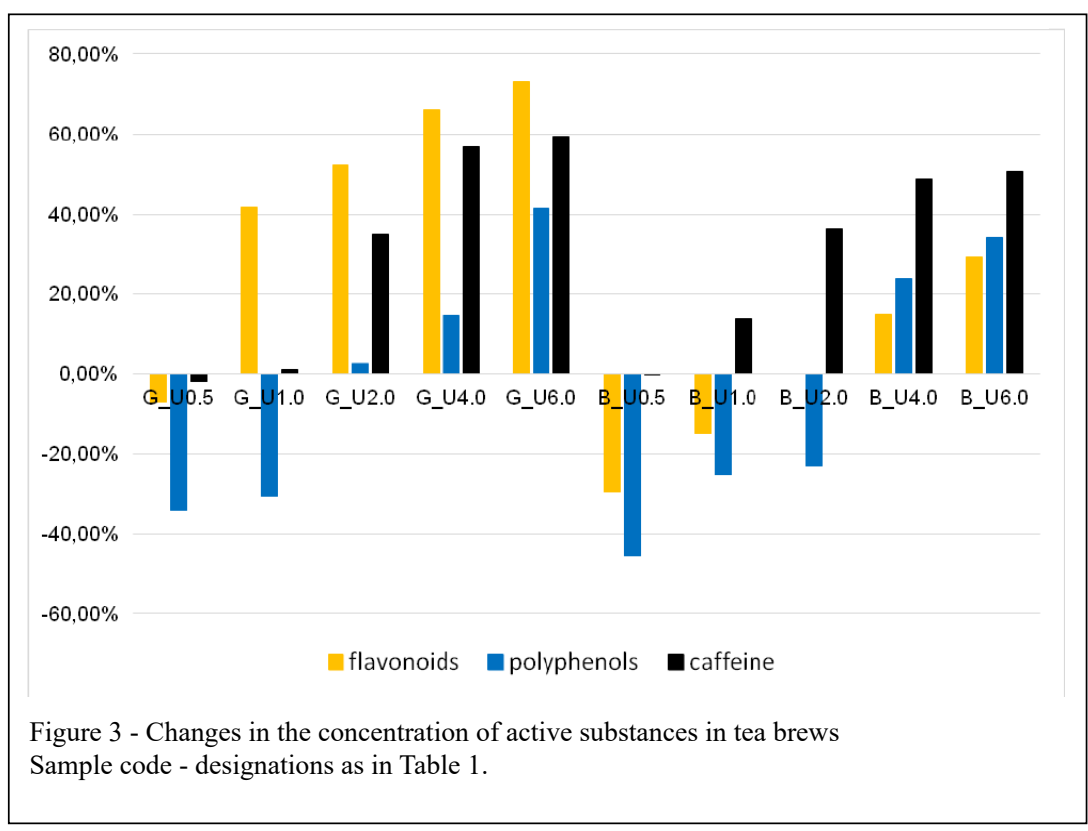

Ciência Rural, v.49, n.11, 2019. 
control sample (Figure 3 ). The lowest concentration of polyphenols was recorded for the black tea brew obtained through brewing with sonication at the shortest sonication time of $0.5 \mathrm{~min}$ (B U0.5) - 29.64 $\mathrm{mg} / 100 \mathrm{~mL}$. Whereas, in the case of green tea brews significantly higher concentrations of polyphenols were obtained. In the sample obtained with sonication applied for 6 min (G_U6.0) the concentration of polyphenols wasreported at the level of $77.51 \mathrm{mg} / 100$ $\mathrm{mL}$. Whereas, the control brew of green tea obtained through traditional brewing $(\mathrm{G} N$ ) contained 54.79 $\mathrm{mg} / 100 \mathrm{~mL}$ of the analyzed substances in conversion to gallic acid, and that level was ca. 1.41-fold lower than the concentration of polyphenols obtained at the maximum sonication time used in the experiment (difference of ca. 41\% - Figure 3). The lowest concentration of polyphenols among the green tea brews was characteristic of the brew obtained with sonication of $0.5 \mathrm{~min}-36.10 \mathrm{mg} / 100 \mathrm{~mL}$.

According to KŁÓDKA et al. (2008), the highest concentrations of polyphenols among the analyzed kinds of tea were characteristic of brews of green tea whose leaves had not been subjected to fermentation as is the case in the production of black tea. Brewing time as well as augmentation with ultrasound had a significant effect on the content of polyphenols in tea brews. Active substances from the group of polyphenols migrate to the brew in the optimal concentration after about 3 minutes of brewing time (LIEBERT et al., 1999). YEN et al. (1997) demonstrated in their study that the largest amounts of polyphenolic substances were obtained in the 5th minute of brewing, and with further exdtension of brewing time their content decreased.

In the case of estimation of the content of caffeine in tea brews it was reported that brews obtained from black tea have a higher content of that alkaloid, from $33.43 \mathrm{mg} / 100 \mathrm{~mL}$ to $50.55 \mathrm{mg} / 100 \mathrm{~mL}$, compared to green tea brews - from $19.96 \mathrm{mg} / 100 \mathrm{~mL}$ to $32.50 \mathrm{mg} / 100 \mathrm{~mL}$. Similar relations were observed by HICKS et al. (1996). SUTEERAPATARANON et al. (2009), and WANG et al. (2008) reported that the content of caffeine in tea varies and depends on the species, cultivation, fermentation conditions, and also on the maturity of the plant at harvest.

For the sample obtained through brewing according to the traditional method (B_N) the content of caffeine was $33.58 \mathrm{mg} / \mathrm{mL}$ and did not differ significantly from that in the black tea brew obtained with sonication applied for $0.5 \mathrm{~min}-33.43$ $\mathrm{mg} / 100 \mathrm{~mL}$, while the highest caffeine content was characteristic of the sample obtained with sonication applied for $6 \mathrm{~min}$ B_U6.0 - $50.55 \mathrm{mg} / 100 \mathrm{~mL}$, which corresponded to caffeine concentration ca. 1.51fold higher than in the control sample. In the case of green tea brews the lowest concentration of caffeine was obtained in the brew prepared during $0.5 \mathrm{~min}$ of brewing with sonication $-19.96 \mathrm{mg} / 100 \mathrm{~mL}$, while the control brew of that tea, obtained in the traditional manner (G_N), had a slightly higher caffeine content $-20.37 \mathrm{mg} / 100 \mathrm{~mL}$. Among the green tea brews obtained with sonication the highest caffeine concentration was characteristic of the sample brewed for ie $6 \mathrm{~min}, \mathrm{G}$ U6.0, with caffeine content of 32.50 $\mathrm{mg} / 100 \mathrm{~mL}$, which increased by ca. $59 \%$ compared to the control green tea brew (Figure 3).

HORŽIĆ et al. (2009) reported that, on average, tea leaves have a content of $2-5 \%$ of caffeine, and its level in the brew varies in relation to the degree of leaf fragmentation, thre amount of tea used, and to the brewing conditions (water temperature and brewing time). Research results obtained by e.g.: MANDEL (2002), and GRAY (1998) showed that caffeine content in a portion of tea brew falls within the range of 15-65 mg, which found support in this study.

Summing up the above, it was observed that the application of sonication has a significant effect on the extraction of active substances, i.e. polyphenols, flavonoids and caffeine from leaves of green and black tea, which is reflected in significantly higher levels of those components in the tea brews obtained. The use of sonication caused an increase in the content of active substances relative to the control brews: for black tea - flavonoids from $1.55 \mathrm{mg} / 100$ $\mathrm{mL}$ to $2.00 \mathrm{mg} / 100 \mathrm{~mL}$ (increase by ca. $29 \%$ ), polyphenols from $54.38 \mathrm{mg} / 100 \mathrm{~mL}$ to $73.07 \mathrm{mg} / 100$ $\mathrm{mL}$ (increase by ca. 34\%), caffeine from $33.58 \mathrm{mg} / 100$ $\mathrm{mL}$ to $50.55 \mathrm{mg} / 100 \mathrm{~mL}$ (increase by ca. $51 \%$ ), for green tea - flavonoids from $6.64 \mathrm{mg} / 100 \mathrm{~mL}$ to 11.49 $\mathrm{mg} / 100 \mathrm{~mL}$ (increase by ca. $73 \%$ ), polyphenols from $54.79 \mathrm{mg} / 100 \mathrm{~mL}$ to $77.51 \mathrm{mg} / 100 \mathrm{~mL}$ (increase by ca. $41 \%$ ), caffeine from $20.37 \mathrm{mg} / 100 \mathrm{~mL}$ to 32.50 $\mathrm{mg} / 100 \mathrm{~mL}$ (increase by ca. $60 \%$ ).

A beneficial effect of ultrasound on the extraction of active substances is reported by many researchers. Amog others, VINATOUR (2001) in a paper on the effect of UAE on the extraction of bioactive components from herbs, STASIAK (2005) - on acceleration of water extraction of sugar from sugar beet chips; CARES et al. (2010) - on the effect of UAE on the extraction of bioactive components, i.e. saponin, from the Quillaja Saponaria Molina tree. In all of those reports the authors noted a positive effect of ultrasound augmented extraction on the acquisition of the component of interest. 
Summarising the results obtined in the study presented herein one can conclude that ultrasound can also be applied for the so-called simple culinary processing which allows the preparation of e.g. tea brews or other drinks, acceptable by the consumers in terms of sensory characteristics, notably richer in health-promoting active substances compared to those brews prepared in the traditional manner. Already now one can try to apply such solutions in household appliances used for the preparation of tea or herbal brews. The application of ultrasound creates the possibility of obtaining brews with similar concentrations of active substances from smaller amounts of raw material, or in shorter time realtive to brews prepared in the traditional manner.

\section{CONCLUSION}

The application of sonication obtained brews characterized by preferred traits in sensory evaluation. The application of ultrasound in the process of tea brewing caused a significant increase in the concentration of active substances in tea brews. The duration of the process of tea brewing augmented with sonication has a significant effect on the concentration of active substances in the ready tea brews - the concentration of active substances is directly proportional to brewing time. Application of ultrasound created the possibility of obtaining brews with similar concentrations of active substances from smaller amounts of raw material, or in shorter time relative to brews prepared in the traditional manner. Green tea brews had higher concentrations of active substances from the group of polyphenols, including flavonoids, compared to analogous green tea brews, while black tea brews were characterized by higher concentrations of caffeine compared to brews prepared from green tea.

\section{ACKNOWLEDGEMENTS}

This work was financed by a statutory activity subsidy from the Polish Ministry of Science and Higher Education for the Faculty of Food Science and Biotechnology of University of Life Sciences in Lublin.

\section{BIOETHICS AND BIOSSECURITY COMMITTEE APPROVAL}

We authors of the article entitled "SENSORY AND CHEMICAL EVALUATION OF TEA BREWS PREPARED WITH THE ASSISTANCE OF ULTRASOUND “ declared, for all due purposes, the project that gave rise to the present data of the same has not been submitted for evaluation to the Ethics Committee of the University /Research Institute "University of
Life Sciences in Lublin /Department of Analysis and Evaluation of Food Quality", but we are aware of the contents of Resolution No. 466, of December 12, 2012 of the Brazilian National Health Council "http://conselho.saude.gov.br/resolucoes/2012/Reso466. pdf" if it involves human.

Thus, the authors assume full responsibility for the presented data and are available for possible questions, should they be required by the competent authorities.

\section{DECLARATION OF CONFLICTS OF INTEREST}

The authors declare no conflict of interests. The founding sponsors had no role in the design of the study; in the collection, analyses, or interpretation of data; in the writing of the manuscript; and in the decision to publish the results.

\section{AUTHORS' CONTRIBUTIONS}

Radosław Kowalski, Jakub Wyrostek and Grażyna Kowalska conceived and designed experiments. Jakub Wyrostek, Grażyna Kowalska, Urszula Pankiewicz and Klaudia Kałwa performed the experiments, Monika Sujka, Artur Mazurek and Marzena Włodarczyk-Stasiak carried out the lab analyses. Radosław Kowalski and Jakub Wyrostek performed statistical analyses of experimental data. Radosław Kowalski, Jakub Wyrostek and Grażyna Kowalska prepared the draft of the manuscript. All authors critically revised the manuscript and approved of the final version.

\section{REFERENCES}

BARYŁKO-PIKIELNA, N., MATUSZEWSKA, I. Sensory Testing of Food. Basics -Methods - Application Kraków: Wydawnictwo Naukowe PTTŻ, 2014, pp 270-274.

CARBONELL-BARRACHINA, A. A. Application of sensory evaluation of food to quality control in the Spanish food industry, Polish Journal of Food and Nutrition Science, v.57, n.4A, p.7176, 2007. Available from: <http://journal.pan.olsztyn.pl/Issue4A-2007,6591>. Accessed: Mar. 08, 2018.

CARES, M. G. et al. Ultasonically assisted extraction of bioactive principles from Quillaja Saponaria Molina. Physics Procedia, v.3, p.168-178, 2010. Available from: <https://doi.org/10.1016/j. phpro.2010.01.024>. Accessed: Oct. 24, 2018. doi: 10.1016/j. phpro.2010.01.024.

GASIŃSKA, A., GAJEWSKA, D. Tea and coffee as the main sources of oxalate in diets of patients with kidney oxalate stones. Annals of the National Institute of Hygiene, v.58, p.61-67, 2007. Available from: $<$ https://pdfs.semanticscholar.org/8862/82642855 1e1c865dfffd726deb6767491b10.pdf>. Accessed: Mar. 19, 2018.

GRAY, J. Caffeine, coffe and health. Nutrition and Food Science, v.6, p.314-319, 1998. Available from: <https://doi. org/10.1108/00346659810235215>. Accessed: Sept. 13, 2018. doi: $10.1108 / 00346659810235215$

HICKS, M. B. et al. Tea preparation and its influence on methyloxantine concentration. Food Research International, v.29, n.2-3, p. 325-330, 1996. Available from: <https://doi. org/10.1016/0963-9969(96)00038-5>. Accessed: Apr. 14, 2018. doi: 10.1016/0963-9969(96)00038-5 
HIGDON, J. V., FREI, B. Tea catechins and polyphenols: Health effects, metabolism, and antioxidant functions. Critical Reviews in Food Science and Nutrition, v.43, p.89-143, 2003. Available from: <https://doi.org/10.1080/10408690390826464>. Accessed: Mar. 28, 2018. doi: 10.1080/10408690390826464.

HORŽIĆ, D. et al. The composition of polyphenols and methylxantines in teas and herbal infusions. Food Chemistry, v.115, p.441-448, 2009. Available from: $<$ https://doi.org/10.1016/j. foodchem.2008.12.022>. Accessed: Feb. 19, 2018. doi: 10.1016/j. foodchem.2008.12.022.

KŁÓDKA, D. et al. Content profile of some selected methylxanthines and phenolic compounds in infusions of various tea types in a crumbled form (dust and fannings) depending on the brewing time. Food, Science. Technology, Quality, v.1, n.56, p.103-113, 2008. Available from: <http://journal.pttz.org/wpcontent/uploads/2018/01/09_Klodka.pdf >. Accessed: Nov. 14, 2018 .

KRAUJALYTE, V. et al. Volatile compounds and sensory characteristics of various instant teas produced from black tea. Food Chemistry, v.194, p.864-872, 2016. Available from: $<$ https://doi.org/10.1016/j.foodchem.2015.08.051>. Accessed: Oct. 11, 2018. doi: 10.1016/j.foodchem.2015.08.051.

LIEBERT, M. et al. Antioxidant properties and total phenolics content of green and black tea under different brewing conditions. Zeitschrift fur Lebensmittel -Untersuchung und - Forschung, v.208, n.3, p.217-220, 1999. Available from: <https://doi. org/10.1007/s002170050406>. Accessed: Mar. 24, 2018. doi: $10.1007 / \mathrm{s} 002170050406$.

MANDEL, H. G. Update on caffeine consumption, disposition and action. Food and Chemical Toxicology, v.40, p.1231-1234, 2002. Available from: $<$ https://doi.org/10.1016/S0278-6915(02)00093-5>. Accessed: Apr. 12, 2018. doi: 10.1016/S0278-6915(02)00093-5.

MASON, T. J. Sonochemistry. Oxford Univ. Press, Oxford, 1999.

PERUCKA, I. Chemical composition of tea leaves. Journal of Elementology (Biuletyn Magnezologiczny), v. 6, n. 3, p. 443$451,2001$.

Polish Pharmacopoeia VI Polish Pharmaceutical Society. Poland: Warsaw, 2002.

POLISH STANDARD PN-ISO 3103 Tea - Preparation of liquor for use in sensory tests, 1996.

SINGELTON, V. L., ROSSI, J. A. JR. Colorimetry of total phenolics with phosphomlybdic-phosphotungstic acid reagents. American Journal of Enology and Viticulture, v.16, p.144-158, 1965.

SOMESWARARAO, CH., SRIVASTAV, P. P. A novel technology for production of instant tea powder from the existing black tea manufacturing process. Innovative Food Science and Emerging Technologies, v.16, p.143-147, 2012. Available from: $<$ https://doi. org/10.1016/j.ifset.2012.05.005>. Accessed: Sept. 19, 2018. doi: 10.1016/j.ifset.2012.05.005.

STASIAK, D. The ultrasound-assisted sugar extraction from sugar beet cossettes. Acta Scientarum Polonorum Technica Agraria, v.4, n.2, p.31-39, 2005. Available from: <http://www.acta.media. pl/pl/action/getfull.php?id=1162>. Accessed: Nov. 24, 2018.

SUTEERAPATARANON, S. et al. Caffeine in Chiang Rai tea infusions: Effects of tea veriety, type, leaf, form and infusion conditions. Food Chemistry, v.114, p.1335-1338, 2009. Available from: $\quad<$ https://doi.org/10.1016/j.foodchem.2008.11.013>. Accessed: Jul. 22, 2018. doi: 10.1016/j.foodchem.2008.11.013.

SZCZĘSNA, T. et al. The effect of nutritional knowledge, education and financial situation on food preferences and nutritional habits of agricultural university students living in students house. Problemy Higieny i Epidemiologii, v.86, n.1, p.30-35, 2005. Available from: <http://www.phie.pl/pdf/phe-2005/phe-2005-1-030.pdf>. Accessed: Mar. 14, 2018.

VINATOUR, J. A. An overview of ultrasonically assisted extraction of bioactive principles from herbs. Ultraconics Sonochemistry, v.8, p.303-313, 2001. Available from: <https://doi.org/10.1016/ S1350-4177(01)00071-2>. Accessed: Oct. 28, 2018. doi: 10.1016/ S1350-4177(01)00071-2.

WANG, H. et al. Tea flavonoids: their functions, ultization and analysis. Trends in Food Science and Technology, v.11, p.152-160, 2000. Available from: <https://doi.org/10.1016/j. lwt.2015.08.045>. Accessed: Sept. 02, 2018. doi: 10.1016/j. lwt.2015.08.045.

WANG, X., et al. Study on the increase mechanism of the caffeine content during the fermentation of tea with microorganisms. Food Chemistry, v.107, p.1086-1091, 2008. Available from: <https:// doi.org/10.1016/S0924-2244(00)00061-3>. Accessed: Mar. 22, 2018. doi: 10.1016/S0924-2244(00)00061-3.

WEISBURGER, J. H. Tea and health: a historical perspective. Cancer Letter, v.114, p.315-317, 1997. Available from: <https:// doi.org/10.1016/S0304-3835(97)04691-0>. Accessed: Mar. 08, 2018. doi: 10.1016/S0304-3835(97)04691-0.

XIA, T. et al.. Impact of ultrasonic-assisted extraction on the chemical and sensory quality of tea infusion. Journal of Food Engineering, v.74, p.557-560, 2006 Available from: $<$ https://doi. org/10.1016/j.jfoodeng.2005.03.043>. Accessed: Jul. 02, 2018. doi: 10.1016/j.jfoodeng.2005.03.043.

YAO, L. H. et al. The kinetics of black tea infusion. Journal of Food Fermentation and Industries, v. 19, p. 38-44, 1993.

YAO, L. H. et al. Compositional analysis of teas from Australian supermarkets. Food Chemistry, v.94, p.115-122, 2006. Available from: $\quad<$ https://doi.org/10.1016/j.foodchem.2004.11.009>. Accessed: Jul. 24, 2018. doi: 10.1016/j.foodchem.2004.11.009.

YEN, G. , et al. Antioxidant and prooxidant effects of various tea extract. Journal of Agriculture and Food Chemistry, v.45, p.3034, 1997. Available from: < https://pubs.acs.org/doi/abs/10.1021/ jf9603994>. Accessed: Dec. 12, 2018. doi: 10.1021/jf9603994.

ZHU. F. et al. Effect of black tea on antioxidant, textural, and sensory properties of Chinese steamed bread. Food Chemistry, v.194, p.1217-1223, 2016. Available from: <https://doi. org/10.1016/j.foodchem.2015.08.110>. Accessed: Apr. 12, 2018. doi: $10.1016 /$ j.foodchem.2015.08.110. 